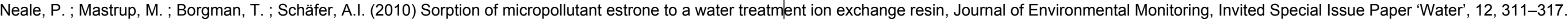
DOI: 10.1039/B913338K

\section{Sorption of micropollutant estrone to a water treatment ion exchange resin}

Peta A. Neale ${ }^{\mathrm{a}}$, Maibritt Mastrup ${ }^{\mathrm{b}}$, Thomas Borgmann ${ }^{\mathrm{b}}$ and Andrea I. Schäfer ${ }^{\mathrm{a}^{*}}$

${ }^{a}$ School of Engineering and Electronics, The University of Edinburgh, Edinburgh, EH9 3JL, United Kingdom

${ }^{\mathrm{b}}$ Ingeniørhøjskolen Odense Teknikum, Niels Bohrs Alle 1,5230 Odense M, Denmark

Submitted to

Journal of Environmental Monitoring - Special Issue 'Water' July 2009

Resubmitted August 2009

* Corresponding author: Andrea Schäfer, E-mail: Andrea.Schaefer@ed.ac.uk, Ph: +44(0)131 650 7209; Fax: +44(0)1316506781

\section{Abstract}

Micropollutants occur in natural waters from a range of sources. Estrogenic compounds are naturally excreted by humans and hence stem predominantly from wastewater effluents. Due to the small size and concentration of such michellots the technology - magnetic ion exchange (MIEX) surface water, was investigated. Estrone interacts with polymeric materials such as ion exchange resins or membranes through a number of mechanisms including specific and non-specific interactions. To understand the mechanisms and subsequence implications of this interaction sorption and desorption of estrone was studied as a function of $\mathrm{pH}$, temperature, natural organic matter concentration, sulfate concentration and ionic strength. The results demonstrated that the resin removed around $70 \%$ estrone at high $\mathrm{pH}$ conditions $(>10.4)$ when estrone was predominantly negatively charged. However, below pH 10.4, when estrone was neutral, approximately $40 \%$ of estrone still sorbed due to hydrogen bonding. The optimum temperature for estrone sorption was ester so observed to be fren 15 to $35^{\circ} \mathrm{C}$. removal due to competition for anion exchange sites. Desorption of estrone was most effective with $2 \mathrm{M} \mathrm{NaCl}$ regeneration brine concentration when estrone was negatively charged (98\% desorption). However, when estrone was neutral there was no significant difference between $1 \mathrm{M}$ and $2 \mathrm{M} \mathrm{NaCl}$. The results presented in this study indicate that polar non-ionic micropollutants were removed by magnetic ion exchange due to sorption to the resin polymer. Consequently, this study has implications for improved understanding of micropollutant removal by such resins. Beyond the possibilities of exploiting ion exchange for the removal of micropollutants, the accumulation of micropollutants on polymeric materials in water treatment is a potential risk to be monitored.

Keywords: Magnetic ion exchange (MIEX ${ }^{\circledR}$ ), natural organic matter, micropollutant, sorption, desorption, water treatment

\section{Introduction}

Water treatment processes are increasingly designed to remove dissolved contaminants and micropollutants that reach water supplies from various sources. Natural organic matter (NOM), for natural compounds into hazardous disinfection by-products. In consequence, a strong base anion exchange resin (AER) that can remove such NOM (weak acidic ions predominantly) has been developed. An example of an AER is magnetic ion exchange resin (MIEX ${ }^{\oplus}$ ) which is a polyacrylate macroporous polymer with strong base quaternary ammonium functional groups for ion exhange and a magnetic iron oxide core to assist with resin agglomeration and recovery. ${ }^{2}$ This resin can be used to remove other contaminants also, such as bromide, sulfate, nitrate, arsenic and chromium, ${ }^{3,4}$ and the process can further be used to control fouling in membrane filtration, where NOM plays an important role. The process can be retrofitted to existing water treatment plants that were not advanced treatment.

Micropollutants, such as natural and synthetic hormones, pesticides and pharmaceutically active products, are ubiquitous in the aquatic environment, and can be considered a cause of concern for human and environmental health. ${ }^{5}$ Estrone is a naturally excreted steroidal hormone, which can also be formed through the oxidation of estradiol. ${ }^{6}$ Natural hormones such as estrone have the potentia to disrupt the endocrine system and consequently have implications for fertility and reproductive health. ${ }^{7,8}$ Studies have shown that low concentrations of estrone $(3 \mathrm{ng} / \mathrm{L})$ can cause behavioural changes in some aquatic organisms ${ }^{9}$ Removal of estrone by conventional sewage treatment plants changes in $\mathrm{A}$ a d by $\mathrm{C}$. (a) effluent compared to the influent concentration due to estadiol degradaion, while other studie have observed average removals of $53-61 \% .{ }^{11-13}$ As a result, estrone is regularly detected in surface waters and sewage effluents at low $\mathrm{ng} / \mathrm{L}$ concentrations. ${ }^{14,15}$

As conventional treatment cannot completely remove micropollutants such as estrone, other removal technologies have been explored including ozonation, advanced oxidation processes and membrane filtration, particularly nanofiltration/reverse osmosis (NF/RO). Studies have demonstrated that estrone can be removed to below detectable limits using ozonation ${ }^{16-18}$ and $\mathrm{ClO}_{2}$ doxidation ${ }^{19}$, while Nghiem et al ${ }^{20}$ found estrone retention by NF/RO membranes varied from 13 to $>90 \%$ due to differences in hormones by ion exchange (IX) resins, Zhang and Zhou ${ }^{21}$ found moderate removal of estrone from solution using a styrene IX resin, with 71 hours required to reach equilibrium. Environmental effects like temperature or water quality such as $\mathrm{pH}$ has not been considered.

Micropollutant removal mechanisms of IX resins other than ion exchange of charged molecules are to date not well understood. Humbert et al. ${ }^{4}$ studied the removal of pesticides atrazine and isoproturon using a range of strong AERs. The study showed pesticide removal ranged from 5-37\% for all AERs, however MIEX ${ }^{\circledR}$ could only remove 5-7\% of pesticides ${ }^{4}$ The low removal was attributed to the non-ionic nature of the pesticides in the experimental conditions. Despite this, specific and non-specific interactions, such as hydrophobically assisted ion exchange and hydrogen bonding, can occur between neutral acidic species such as phenolic groups (at $\mathrm{pH} 7$ ) and the polymer. ${ }^{22,23}$ The porous nature of the resin can assist with the removal of neutrally charged contaminants. ${ }^{24}$ It is also likely that non-ionic micropollutants can interact with the resin polymer through hydrogen bonding ${ }^{25}$, increasing potential non-ionic micropollutant uptake. While micropollutant removal is generally a desired phenomenon in water treatment, it can also occur as a side effect with accumulation of micropollutants on the resin and concentration in the brine. 


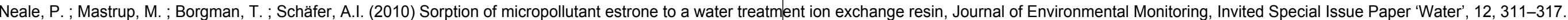
DOI: $10.1039 / \mathrm{B} 913338 \mathrm{~K}$

The resin is regenerated using a $\mathrm{NaCl}$ brine which exchanges any anions sorbed to the quaternary ammonium functional group for chloride ions. ${ }^{26}$ Caustic compounds such as $\mathrm{NaOH}$ can be added to the $\mathrm{NaCl}$ brine to enhance desorption. It is to date not understood if regeneration only reverses micropollutants removed by ion exchange or also other sorption processes.

The purpose of the study is to investigate the removal as well as partitioning mechanisms of estrone and to assess the influence of water chemistry parameters such as $\mathrm{pH}$ and ionic strength. As estrone and to assess is predoninately ingatively charged at $\mathrm{pH}>10.4$, studying the influence of can improve understanding of both ion exchange and specific and non-specific interaction mechanisms. Temperature effects as well as estrone removal in the presence of competing ions, such as NOM and sulfate, will be studied to understand the influence of competition. Finally, the release of estrone from the resin during regeneration will be investigated in order to understand any associated treatment liabilities and risks concerning accidental contamination of water as well as the potential presence of micropollutants in brines following their accumulation on the resin.

\section{Experimental}

\section{Chemicals}

All chemicals used are of analytical grade. Radiolabelled $\left[2,4,6,7-{ }^{3} \mathrm{H}\right]$ estrone was purchased from Sigma Aldrich (Saint Louis, US). Estrone is a bipolar hormone, with an acid dissociation constan $\left(\mathrm{pK}_{\mathrm{a}}\right)$ of 10.4. ${ }^{27}$ The background electrolyte was $1 \mathrm{mM} \mathrm{NaHCO}$. The $\mathrm{pH}$ was adjusted using $1 \mathrm{M}$ $\mathrm{HCl}$ and $1 \mathrm{M} \mathrm{NaOH}$. Natural organic matter (NOM), from Brisbane Water National Park in Australia, was concentrated using microfiltration and RO, and was extensively characterised by Schäfer. $^{28}$

\section{Magnetic ion exchange resin $\left(\right.$ MIEX $\left.^{\circledR}\right)$}

The resin was supplied by Orica Watercare (Melbourne, Australia). The concentration of resin used in the experiment was $10 \mathrm{~mL} / \mathrm{L}$. Industrial applications typically use doses ranging from 2 to 20 $\mathrm{mL} / \mathrm{L}^{29}$, however, previous studies have indicated that a dose of $8-10 \mathrm{~mL} / \mathrm{L}$ is optimal for NOM and inorganic anion removal. ${ }^{4,2}$

The sorption experiments were conducted in $100 \mathrm{~mL}$ Erlenmeyer flasks containing $50 \mathrm{~mL}$ of MilliQ water with $1 \mathrm{mM} \mathrm{NaHCO}$ background electrolyte. The initial estrone concentrations were $1,5,10$ 50,100 and $500 \mathrm{ng} / \mathrm{L}$, which is in the range of typical surface and wastewaters. Erlenmeyer flasks 50,100 and $500 \mathrm{ng} / \mathrm{L}$, which is in the range of typical surface and wastewaters. Erlenmeyer flasks
were placed in a temperature controlled Bioline incubator shaker (Alexandria, Australia). Before each experiment $1 \mathrm{~mL}$ from each flask was removed for analysis, and $0.5 \mathrm{~mL}(0.113 \mathrm{~g})$ of resin slurry was added to each flask using $5 \mathrm{~mL}$ single use syringes, giving a total concentration of 10 $\mathrm{mL} / \mathrm{L}$. Flasks were shaken for 2 hours at $200 \mathrm{rpm}$, and a sample of $1 \mathrm{~mL}$ was collected. Adsorption kinetics reached equilibrium within 25 minutes. In the $\mathrm{pH}$ sorption experiments the $\mathrm{pH}$ was adjusted to $3,5,8,9,10,11$ and 12 using $1 \mathrm{M} \mathrm{HCl}$ and $\mathrm{NaOH}$ and the temperature was kept constant at 25 ${ }^{\circ} \mathrm{C}$. In the temperature experiments the temperture was adjusted to $15,25,35,45$ and $55^{\circ} \mathrm{C}$ at $\mathrm{pH} 8$. The $\mathrm{NOM}$ ionic strenth and sulfat were studied at $\mathrm{pH} 8$ and 11 and a constan temperature of $25^{\circ} \mathrm{C}$. The $\mathrm{NOM}$ concentrations studied were $0,10,30$ and $100 \mathrm{mg} / \mathrm{L}(0,0.63,1.89$ $6.3 \mathrm{mgC} / \mathrm{L}$ ), while in the ionic strength sorption experiments $\mathrm{NaCl}$ concentrations of $0,20,50,100$ and $200 \mathrm{mM}$ were studied. For the sulfate experiments the $\mathrm{SO}_{4}{ }^{2-}$ concentrations were 0,5 and 20 $\mathrm{mM}$.

The desorption experiments were also conducted in $100 \mathrm{~mL}$ Erlenmeyer flasks following the 100

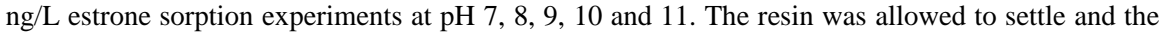
supernatant was decanted and $50 \mathrm{~mL}$ of MilliQ water was added. The effect of ionic strength using $\mathrm{NaCl}$ concentrations of 0,1 and $2 \mathrm{M}$ was studied. The $\mathrm{pH}$ was adjusted to $7,8,9,10$ and $11.1 \mathrm{~mL}$ of initial solution was removed for analysis. The flasks were shaken in the incubator shaker at 200 rpm for 1 hour and samples of $1 \mathrm{~mL}$ were collected at 2, 5, 10,15, 30 and 60 minutes.

\section{Analysis}

Scintillation counting was used to detect estrone at very low concentrations. Samples from sorption and desorption experiments $(1 \mathrm{~mL})$ were added to $9 \mathrm{~mL}$ of Ultima Gold LLT scintillation cocktail (Perkin Elmer, Boston, US) and shaken until clear. The samples settled and analysed using a Packard Instruments Tri-Carb ${ }^{\circledR}$ liquid scintillation cour Boston, US) where they were left to count for 5 minutes each. The activity in counts per minute (cpm) was converted to estrone concentration in $\mathrm{ng} / \mathrm{L}$. The percentage of estrone removal by sorption is calculated using Equation 1, while the mass of estrone removed per mass of resin is calculated using Equation 2. The sorption isotherms are calculated as the mass of estrone removed per mass of resin as a function of the estrone equilibrium concentration. This represents the freely dissolved hormone concentration in solution at equilibrium. The percentage of estrone desorbed with the addition of $\mathrm{NaCl}$ brine can also be calculated using Equation 1.

$$
\begin{gathered}
\text { Sorption }(\%)=1-\frac{C_{E}}{C_{I}} \cdot 100 \% \\
Q_{E}=\frac{\left(C_{I}-C_{E}\right) \cdot V_{W}}{M_{I X}}
\end{gathered}
$$

Where: $\mathrm{C}_{\mathrm{E}}$ is the concentration of estrone at equilibrium $(\mathrm{ng} / \mathrm{L})$

$\mathrm{C}_{\mathrm{I}}$ is the initial concentration of estrone prior to resin addition $(\mathrm{ng} / \mathrm{L})$

$\mathrm{Q}_{\mathrm{E}}$ is the mass of estrone removed per mass of resin $(\mathrm{ng} / \mathrm{g})$

$\mathrm{V}_{\mathrm{W}}$ is the solution volume $(\mathrm{L})$

$\mathrm{M}_{\mathrm{IX}}$ is the mass of resin added (g)

A field emission scanning electron microscope (Hitachi s-900 FESEM) at $20 \mathrm{kV}$ was used to image the resin.

\section{Results and discussion}

\section{Characteristics of MIEX ${ }^{\oplus}$}

Within the literature, the resin beads are suggested to have an average diameter of 150 to $180 \mu \mathrm{m}$, which is approximately 2 to 5 times smaller than other commonly used IX resins. ${ }^{30}$ As a result, it has a greater surface area to volume ratio compared to larger IX resins thus increasing micropollutant removal. ${ }^{31}$ However, the average diameter of the resin in Figure 1 appears to be considerably less than what is suggested in the literature, with particles as small as 5 to $10 \mu \mathrm{m}$ observed. Therefore, it is likely that the resin is susceptible to mechanical break-up. The charge of the resin is unlikely to be influenced by solution $\mathrm{pH}$, as the quaternary ammonium functional groups give the resin a positive charge in both acidic and alkaline solutions.

\section{[Figure 1]}

\section{Sorption}

To understand the sorption mechanisms of charged and uncharged estrone the influence of $\mathrm{pH}$ is studied. $\mathrm{pH}$ can influence the speciation and charge of estrone as it has a $\mathrm{pK}_{\mathrm{a}}$ of 10.4. This has implications for the transport and behaviour of estrone within natural and engineered systems as charge can influence hormone removal. ${ }^{27}$ The removal of uncharged estrone from $\mathrm{pH} 3$ to 10 is similar (Figure 2a), with approximately $40 \%$ removal. At $\mathrm{pH} 11$ and 12 when estrone is negatively 


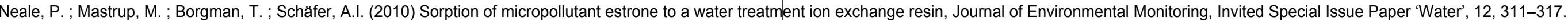

charged, estrone removal increases substantially to $60-70 \%$. Figure $2 \mathrm{~b}$ shows the mass of estrone sorbed per mass of resin as a function of $\mathrm{pH}$, and this also indicates a significantly increased isotherm slope at $\mathrm{pH} 11$ and 12

[Figure 2]

Due to the strong base quaternary ammonium functional groups, the resin has a strong $\mathrm{pH}$ tolerance ${ }^{32}$ and hence observed changes in estrone removal can be attributed to the dissociation of estrone. Estrone is $99.5 \%$ protonated at $\mathrm{pH} 8$ and is $82-97 \%$ dissociated at $\mathrm{pH} 11$ and 12 . As the estrone. Estrone is $99.5 \%$ protonated at $\mathrm{pH} 8$ and is $82-97 \%$ dissociated at $\mathrm{pH} 11$ and 12 . As the
dominant removal mechanism for the resin is ion exchange, estrone removal is greatest when estrone is predominantly negatively charged at $\mathrm{pH}>10.4$ (Figure 3 ). However, at $\mathrm{pH}$ values lower than the $\mathrm{pK}_{\mathrm{a}}$, moderate estrone removal by also observed (40\%) which is surprising. The removal of non-ionic estrone can be explained with physical interactions such as van der Waals forces and hydrogen bonding with the polyacrylate polymer. ${ }^{22}$ The mechanism of interaction is likely to be absorption, compared to adsorption, due to the resin material. The polyacrylate coating is similar to the coating of some fibres used for solid-phase microextraction (SPME), and studies have indicated that micropollutants are removed by such SPME fibres through absorption. ${ }^{33}$ Further, the linearity that micropollutants are removed by such SPME fibres through absorption. ${ }^{33}$ Further, the linearity
of the sorption isotherms in Figure $2 \mathrm{~b}$ suggests that absorption is indeed the dominant mechanism. ${ }^{34}$

\section{[Figure 3]}

The significant removal of non-ionic estrone suggests that hydrogen bonding is the dominant physical sorption mechanism. Estrone contains a phenolic hydroxyl group which acts as a hydrogen donor and acceptor, hence it is bipolar, and a ketone group which is a strong hydrogen acceptor ${ }^{35}$ The polyacrylate resin also contains polar functional groups such as ketone and ammonium moieties, and therefore hydrogen bonding is indeed possible. Previous studies have observed strong estrone sorption to membrane polymers and it is suggested that this is due to hydrogen bonding, as well as non-specific interactions. ${ }^{27,36}$ Schäfer et al. ${ }^{27}$ found estrone sorption to the membrane polymers significantly decreased as the $\mathrm{pH}$ exceeded the $\mathrm{pK}_{\mathrm{a}}$ and hydrogen bonding capacity decreased. In the case of the resin, the dissociation of estrone adds the potential of ion exchange, which is indeed observed.

Temperature is of interest as it may have implications for micropollutant removal kinetics. As estrone is non-ionic at $\mathrm{pH} 8$, removal by the resin is due to physical sorption. The removal of estrone as a function 15 to $35^{\circ} \mathrm{C}$, 15 to $35^{\circ} \mathrm{C}$ with averge rennoves to $45^{\circ} \mathrm{C}$ the average estrone removal decreases to $31 \%$, and to $23 \%$ at $55^{\circ} \mathrm{C}$. The sorption isotherms (Figure $4 \mathrm{~b}$ ) indicate a similar mass of estrone removed per mass of resin from 15 to $35^{\circ} \mathrm{C}$

\section{[Figure 4]}

The effect of temperature on NOM removal by magnetic ion exchange resin has been studied previously. Humbert et al. ${ }^{4}$ studied NOM removal from 6 to $36^{\circ} \mathrm{C}$ and found no difference in removal between 6 and $26^{\circ} \mathrm{C}$, however removal increased as the temperature increased at $36^{\circ} \mathrm{C}$ due to accelerated kinetics. In contrast, Semmens et al. ${ }^{37}$ compared NOM removal by the resin in summer $\left(24^{\circ} \mathrm{C}\right)$ and winter $\left(6^{\circ} \mathrm{C}\right)$ conditions and found a $12 \%$ reduction in NOM removal in colder summer $\left(24^{\circ} \mathrm{C}\right)$ and winter $\left(6^{\circ} \mathrm{C}\right)$ conditions and found a $12 \%$ reduction in NOM removal in colder
conditions due to slower NOM uptake. Chen ${ }^{38}$ found that NOM removal was similar at $25^{\circ} \mathrm{C}$ and conditions due to slower NOM uptake. Chen ${ }^{38}$ found that NOM removal was similar at $25^{\circ} \mathrm{C}$ and
$35^{\circ} \mathrm{C}$ with a polyacrylic IX resin. The variations in the literature are due to different experimental $35^{\circ} \mathrm{C}$ with a polyacrylic IX resin. The variations in the literature are due to different experimental conditions, such as equilibrium time and resin doses. However, at $\mathrm{pH} 8$ estrone is not interacting with the resin through ion exchange, as NOM does, therefore it is difficult to compare these results or identify a coherent mechanism. Similar to this study, a decrease in micropollutant uptake by polyacrylate SPME fibres have previously been observed at high temperatures. ${ }^{39}$ As sorption to polyacrylate is diffusion controlled, the temperature accelerates removal kinetics. ${ }^{40}$ However, as the temperature increases to 45 and $55^{\circ} \mathrm{C}$ the polyacrylate-water partition coefficient decreases ${ }^{39}$, and this may lead to a reduction in estrone removal at high temperatures.

The sorption of estrone is also studied in the presence of varying NOM, ionic strength and sulfate concentrations. NOM and sulfate are selected as they may compete with estrone for ion exchange concentrations. NOM cen affect the ion exchange process. Experiments are conducted at $\mathrm{pH} 8$ and 11 to study the influence of estrone dissociation on removal. In Figure 5a the isotherm slope decreases as NOM concentration increases at $\mathrm{pH} 8$, indicating a reduction in estrone removal with increasing NOM concentration. However, there appears to be no significant difference in sorption at $\mathrm{pH} 11$ (Figure 5b). This change in sorption is related to estrone charge. As estrone is neutrally charged at $\mathrm{pH} 8$ it can only be removed through physical interactions, while the anionic NOM can be removed through ion exchange, which is a stronger interaction. Therefore, as more NOM is removed less estrone can be sorbed by the resin. It is likely this is due to the significantly higher NOM concentration $(10-100 \mathrm{mg} / \mathrm{L}$ compared to $1-500 \mathrm{ng} / \mathrm{L}$ ) which can block estrone sorption sites. However, at $\mathrm{pH} 11$ when estrone is negatively charged it can out-compete NOM for binding sites, therefore there is no significant difference in estrone sorption with increasing NOM concentration. Ion exchange to the macroporous IX resin is diffusion controlled ${ }^{41}$, therefore estrone out-competes NOM due to the significantly lower molecular weight of estrone $(270.4 \mathrm{~g} / \mathrm{mol}$ versus $<1000 \mathrm{~g} / \mathrm{mol})$ which results in a greater diffusion constant

[Figure 5]

The influence of ionic strength $(\mathrm{NaCl})$ is studied as it may shield electrostatic interactions between estrone and the resin functional groups. ${ }^{42}$ Figure 6 a shows for $\mathrm{pH} 8$ a slight decrease in estrone sorption in the presence of $20 \mathrm{mM} \mathrm{NaCl}$, however there is no difference in isotherm slope as the sorption in the presence of $20 \mathrm{mM} \mathrm{NaCl}$, however there is no difference in isotherm slope as the
ionic strength increases from $20 \mathrm{mM}$ to $200 \mathrm{mM} \mathrm{NaCl}$. For pH 11 a significant reduction in ionic strength increases from $20 \mathrm{mM}$ to $200 \mathrm{mM} \mathrm{NaCl}$. For $\mathrm{pH} 11$ a significant reduction in
isotherm slope with increasing ionic strength is observed, indicating decreasing estrone sorption isotherm slope with increasing ionic strength is observed, indicating decreasing estrone sorption
(Figure 6b). At high ionic strength the charge of estrone and resin functional groups are shielded reducing the ion exchange capability, resulting in decreasing sorption as a function of ionic strength at $\mathrm{pH}$ 11. Below the $\mathrm{pK}_{\mathrm{a}}$ of estrone the high ionic strength did not influence the sorption, as ion exchange is not the removal mechanism.

[Figure 6]

Sulfate is a multivalent anion $\left(\mathrm{SO}_{4}{ }^{2-}\right)$, and previous studies indicate that the presence of sulfate can reduce the removal of organic matter as it can compete for anion exchange sites. ${ }^{22,43}$ Consequently, the influence of estrone removal in the presence of sulfate is studied to determine if this influences estrone removal. Figure 7a shows a reduction in isotherm slope in the presence of sulfate for $\mathrm{pH} 8$ while in Figure $7 \mathrm{~b}$ little difference in estrone sorption at $\mathrm{pH} 11$ is observed when ion exchange occurs. Similar to NOM, the concentration of sulfate is considerably higher $\left(\mathbf{4 - 1 8 5 0 \times 1 0 ^ { - 9 }} \mathrm{mM}\right.$ of estrone versus $5-20 \mathrm{mM}$ of sulfate) reducing estrone sorption sites at $\mathrm{pH} 8$.

[Figure 7]

\section{Desorption}

IX resins are regenerated through reverse ion exchange, where contaminants are substituted for, in this case, chloride ions (Figure 8). ${ }^{44}$ It is unknown if micropollutants, such as estrone, can be removed from the resin by regeneration, and for this reason the influence of ionic strength on estrone desorption as a function of $\mathrm{pH}$ is measured using MilliQ water $(0 \mathrm{M}), 1 \mathrm{M}$ and $2 \mathrm{M} \mathrm{NaCl}$ (Figure 9). Desorption is lowest in MilliQ water with 33-42\% desorption, followed by $1 \mathrm{M} \mathrm{NaCl}$ 


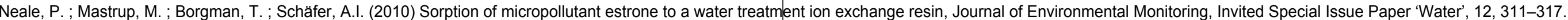
DOI: $10.1039 / \mathrm{B} 913338 \mathrm{~K}$

with 59-67\% estrone desorption and 58-98\% at $2 \mathrm{mM}$. In both MilliQ water and $1 \mathrm{M} \mathrm{NaCl}$ the resin appears to demonstrate some degree of regeneration meaning that the contaminants are likely to desorb if the water quality varies, and that ion exchange is not the mechanism as there is no chlorine in MilliQ water. This indicates that pure water may be contaminated by micropollutants sorbed to the resin. At $2 \mathrm{M} \mathrm{NaCl}$ from $\mathrm{pH} 7$ to 10 desorption is similar to $1 \mathrm{M} \mathrm{NaCl}$ with 58-62\% desorption. At $\mathrm{pH} 11$, when estrone is $82 \%$ negatively charged, there is $98 \%$ desorption of estrone, indicating that an ionic strength of $2 \mathrm{M}$ is sufficient to regenerate the negatively charged estrone. No difference in desorption as a function of $\mathrm{pH}$ is observed for MilliQ water or $1 \mathrm{M} \mathrm{NaCl}$, suggesting that regeneration is a $\mathrm{NaCl}$ concentration dependent process.

\section{[Figure 8]}

[Figure 9]

\section{Conclusions}

The improved removal of steroidal hormones such as estrone from water and wastewater is of great importance. The application of MIEX $^{\circledR}$ to remove estrone is influenced by the solution chemistry, temperature and the presence of competing anions. When estrone is negatively charged, the resin can remove as much as $70 \%$ of estrone, and up to $98 \%$ can be desorbed using $\mathrm{NaCl}$. However, a neutral $\mathrm{pH}$ values, more common in wastewater treatment applications, the removal is significantly less (40\%), with desorption up to $67 \%$. Results imply that the application of the resin combined with another water treatment mechanism, such as membrane filtration or advanced oxidation, may be a good and energy efficient option to ensure significant removal of charged micropollutants from water. An impont implication of this study is that polynic resins a lo concen micropollutants resulting in an elevated concentration in the resin material and the brines from regeneration processes. The disposal and treatment of such brines require solid future investigation, as does the risk of release of micropollutants if ionic strength or $\mathrm{pH}$ of vary accidentally.

\section{Acknowledgements}

Orica Watercare (Melbourne, Australia) are thanked for provision of MIEX ${ }^{\circledR}$ sample. Professor Menachem Elimelech is thanked for revisions of the manuscript during his time in Edinburgh as Royal Academy of Engineering Distinguished Visiting Fellow.

\section{References}

C. J. Johnson and P. C. Singer, Water Res., 2004, 38, 3738-3750.

T. H. Boyer and P. C. Singer, Water Res., 2005, 39, 1265-1276.

A. K. Jha, A. Bose and J. P. Downey, Sep. Sci. Technol., 2006, 41, 3297-3312.

A. K. Jha, A. Bose and J. P. Downey, Sep. Sci. Technol., 2006, 41, 3297-3312.

H. Humbert, H. Gallard, H. Suty and J.-P. Croué, Water Res., 2005, 39, 1699-1708.
R. P. Schwarzenbach, B. I. Escher, K. Fenner, T. B. Hofstetter, C. A. Johnson, U. von Gunten and B. Wehrli, Science, 2006, 313, 1072-1077.

G. G. Ying, R. S. Kookana and Y.-J. Ru, Environ. Int., 2002, 28, 545-551.

7. S. Jobling, M. Nolan, C. R. Tyler, G. Brighty and J. P. Sumpter, Environ. Sci. Technol., 1998, 32, 2498-2506.

8. S. Jobling, S. Coey, J. G. Whitmore, D. E. Kime, K. J W V Van Look, B. G. McAllister, N. Beresford, A. C. Henshaw, G. C. Brightly, C. R. Tyler and J. P. Sumpter, Biol. Reprod. 2002, 67, 515-524.

9. C. A. Murphy, N. E. Stacey and L. D. Corkum, J. Chem. Ecol., 2001, 27, 1573-1561.

10. M. Carballa, F. Omil, J. M. Lema, M. Llompart, C. García-Jares, I. Rodríguez, M. Gómez and T. Ternes, Water Res., 2004, 38, 2918-2926.

11. A. C. Johnson, A. Belfroid and A. Di Corcia, Sci. Total Environ., 2000, 256, 163-173.
12. M. R. Servos, D. T. Bennie, B. K. Burnison, A. Jurkovic, R. McInnis, T. Neheli, A. Schnell, P. Seto, S. A. Smyth and T. A. Ternes, Sci. Total Environ., 2005, 336, 155-170.

13. G. D'Ascenzo, A. Di Corcia, A. Gentili, R. Mancini, R. Mastropasqua, M. Nazzari and R. Samperi, Sci. Total Environ., 2003, 302, 199-209.

14. D. W. Kolpin, E. T. Furlong, M. T. Meyer, E. M. Thurman, S. D. Zaugg, L. B. Barber and H. T. Buxton, Environ. Sci. Technol., 2002, 36, 1202-1211.

15. C. Baronti, R. Curini, G. D'Ascenzo, A. Di Corcia, A. Gentili and R. Samperi, Environ. Sci. Technol., 2000, 34, 5059-5066.

16. T. A. Ternes, J. Stüber, N. Herrmann, D. McDowell, A. Ried, M. Kampmann and B. Teiser, Water Res., 2003, 37, 1976-1982.

17. M. M. Huber, T. A. Ternes and U. von Gunten, Environ. Sci. Technol., 2004, 38, 5177 5186 .

18. H. Zhang, H. Yamada and H. Tsuno, Environ. Sci. Technol., 2008, 42, 3375-3380.

M. M. Huber, S. Korhonen, T. Ternes and U. von Gunten, Water Res., 2005, 39, 3607-3617. L. D. Nghiem, A. Manis, K. Soldenhoff and A. I. Schäfer, J. Membr. Sci., 2004, 242, 37-45. Y. Zhang and J. L. Zhou, Water Res., 2005, 39, 3991-4003.

Y. Tan and J. E. Kilduff, Water Res, 2007, 41, 421j1-4221.

P. Li and A. K. SenGupta, React. Funct. Polym., 2004, 60, 27-39.

P. Li and A. K. SenGupta, React. Funct. Polym., 2004, 60, 27-39.

K. Shorrock and B. Drage, Water Environ. J., 2006, 20, 65-70.
B. Bolto, D. Dixon, R. Eldridge, S. King and K. Linge, Water Res., 2002, 36, 5057-5065.

M. Kitis, B. I. Harman, N. O. Yigit, M. Beyhan, H. Nguyen and B. Adams, React. Funct. Polym., 2007, 67, 1495-1504.

27. A. I. Schäfer, L. D. Nghiem and T. D. Waite, Environ. Sci. Technol., 2003, 37, 182-188.

28. A. I. Schäfer, Natural Organics Removal Using Membranes: Principles, Performance, and Cost, CRC Press, Boca Raton, 2001.

29. J. Y. Morran, M. Drikas, D. Cook and D. B. Bursill, Water Sci. Technol.: Water Supply, 2004, 4, 129-137.

30. P. C. Singer and K. Bilyk, Water Res., 2002, 36, 4009-4022.

31. A. Nel, T. Xia, L. Mädler and N. Li, Science, 2006, 311, 622-627.

32. T. H. Boyer and P. C. Singer, Environ. Sci. Technol., 2008, 42, 608-613.

33. W. H. J. Vaes, C. Hamwijk, E. Urrestarazu Ramos, H. J. M. Verhaar and J. L. M. Hermens, Anal. Chem., 1996, 68, 4458-4462.

34. R. P. Schwarzenbach, P. W. Gschwend and D. M. Imboden, Environmental Organic Chemistry, 2nd edn., John Wiley \& Sons, Inc., Hobeken, 2003.

35. K.-U. Goss and R. P. Schwarzenbach, J. Chem. Educ., 2003, 80, 450-455.

36. L. D. Nghiem, A. I. Schäfer and M. Elimelech, Environ. Sci. Technol., 2004, 38, 1888-1896.

37. M. J. Semmens, M. Burckhardt, D. Schuler, P. Davich, M. Slunjski, M. Bourke and H. M. J. Semmens, M. Burckhardt, D. Schuler, P. Davich, M. Slunjski,
Nguyen, American Water Works Association Conference, Denver, 2000 .

P. H. Chen, Environ. Int., 1999, 25, 655-662.

I. Citová, R. Sladkovský and P. Solich, Anal. Chim. Acta, 2006, 573-574, 231-241.

H. Lord and J. Pawliszyn, J. Chromatogr. A, 2000, 902, 17-63.

P. Li and A. K. SenGupta, Environ. Sci. Technol., 2000, 34, 5193-5200.

L. D. Nghiem and A. I. Schäfer, Environ. Eng. Sci., 2002, 19, 441-451.

T. H. Boyer and P. C. Singer, Water Res., 2006, 40, 2865-2876.

B. Bolto, D. Dixon and R. Eldridge, React. Funct. Polym., 2004, 60, 171-182.

H. Hubicka and D. Kolodynska, Hydrometallurgy, 2001, 62, 107-113. 


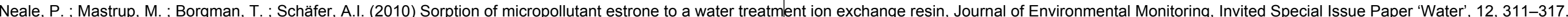
DOI: 10.1039/B913338K

\section{List of Figure}

Figure 1: Field emission scanning electron microscope (FESEM) image of the magnetic ion exchange resin.

Figure 2: a) Removal of estrone and b) sorption isotherms for estrone as a function of $\mathrm{pH}$ (background electrolyte $1 \mathrm{mM} \mathrm{NaHCO}$ ).

Figure 3: Primary mechanisms of estrone removal by anion exchange resin as a) physical sorption and b) ion exchange (adapted from $\mathrm{Li}$ and SenGupta ${ }^{23}$ and Hubicka and Kolodynska. ${ }^{45}$ ).

Figure 4: a) Removal of estrone and b) sorption isotherms for estrone as a function of temperature (background electrolyte $1 \mathrm{mM} \mathrm{NaHCO} 3, \mathrm{pH}$ 8).

Figure 5: Sorption isotherms for estrone as a function of natural organic matter (NOM) concentration at a) $\mathrm{pH} 8$ and b) $\mathrm{pH} 11$ (background electrolyte $1 \mathrm{mM} \mathrm{NaHCO}_{3}$ ).

Figure 6: Sorption isotherms for estrone as a function of ionic strength $(\mathrm{NaCl})$ at a) $\mathrm{pH} 8$ and b) $\mathrm{pH}$ 11 (background electrolyte $1 \mathrm{mM} \mathrm{NaHCO}$ ).

Figure 7: Sorption isotherms for estrone as a function of sulfate concentration at a) $\mathrm{pH} 8$ and b) $\mathrm{pH}$ 11 (background electrolyte $1 \mathrm{mM} \mathrm{NaHCO}_{3}$ ).

Figure 8: Resin regeneration mechanism using $\mathrm{NaCl}$.

Figure 9. Desorption of estrone in MilliQ water, $1 \mathrm{M} \mathrm{NaCl}$ and $2 \mathrm{M} \mathrm{NaCl}$ as a function of $\mathrm{pH}$ (background electrolyte $1 \mathrm{mM} \mathrm{NaHCO}_{3}$ ).
Figure

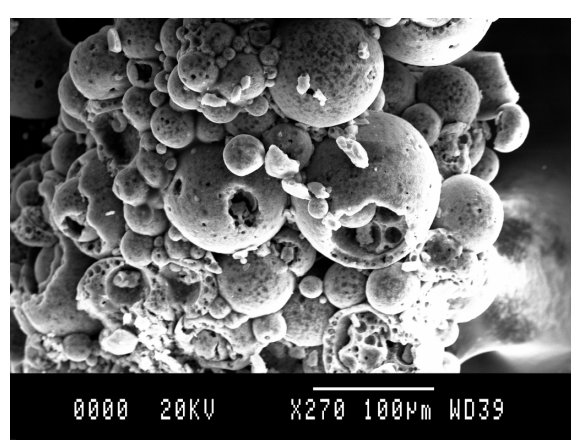




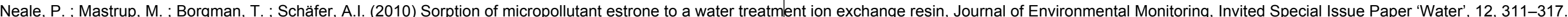
DOI: 10.1039/B913338K

Figure 2

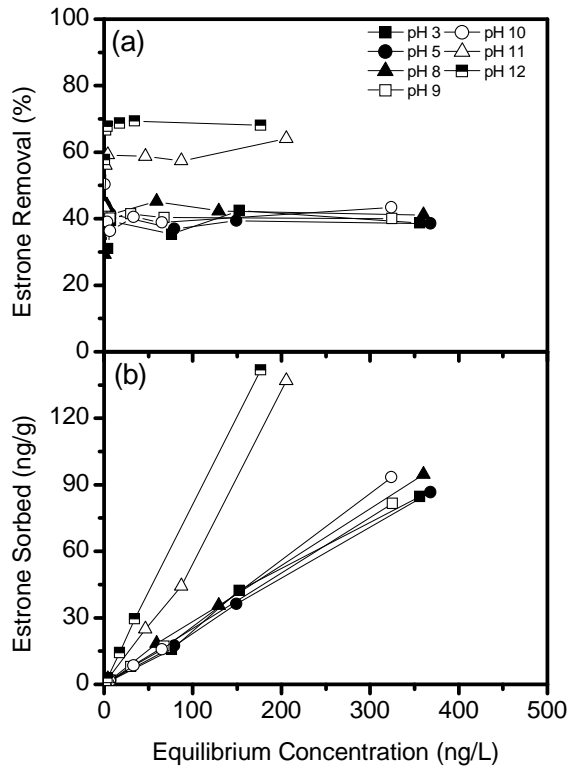

Figure 3

Anion Exchange Resin$$
\begin{gathered}
\text { Polyacryla } \\
\text { Resin }
\end{gathered}
$$<smiles>CCC(C)c1ccc(C)cc1</smiles>

Quaternary

Ammonium

Group

Group

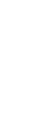

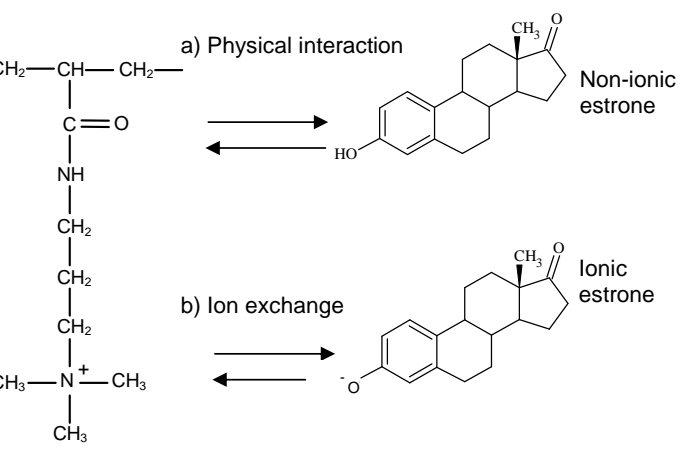




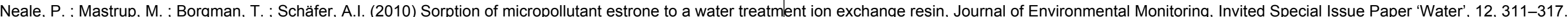
DOI: 10.1039/B913338K

Figure 4
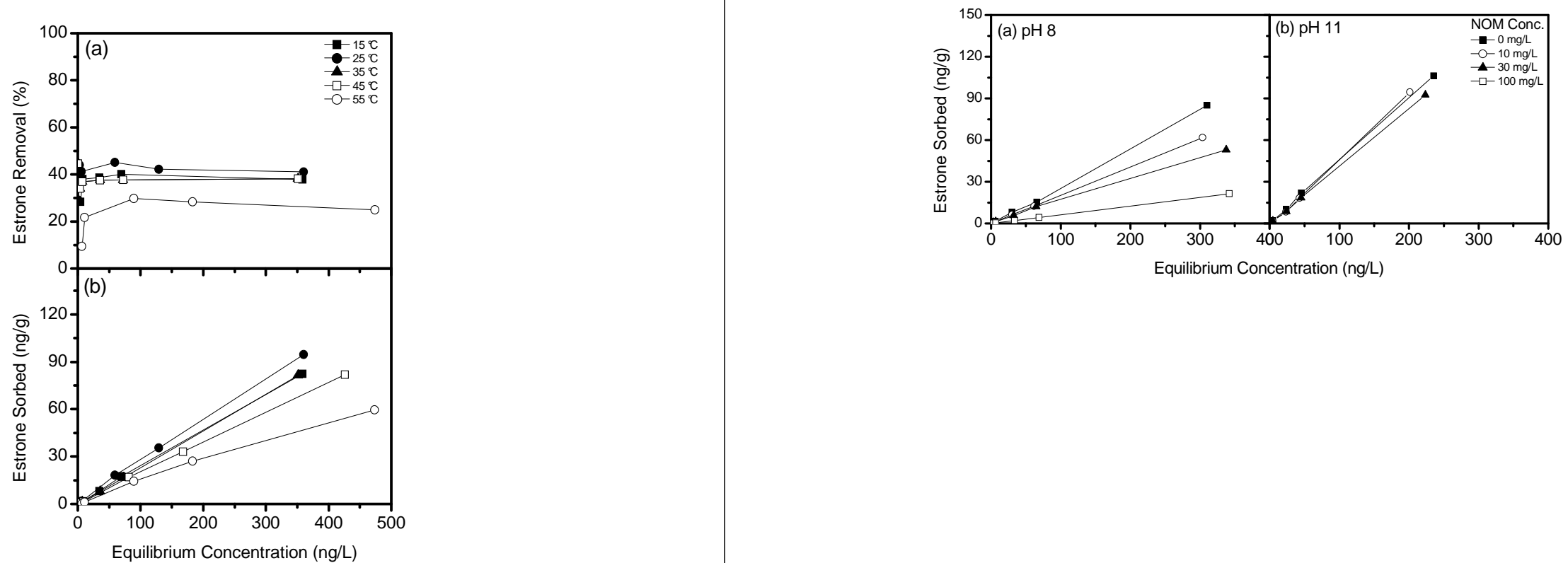


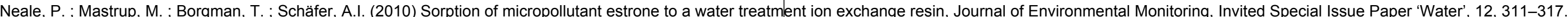
DOI: 10.1039/B913338K

Figure 6

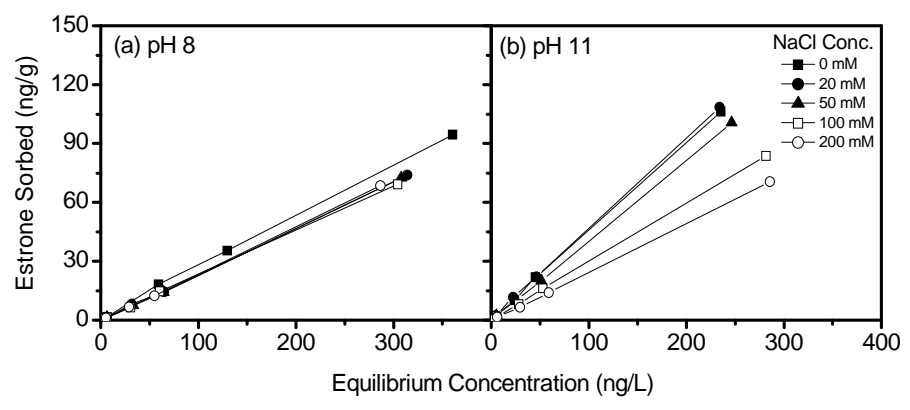

Figure 7

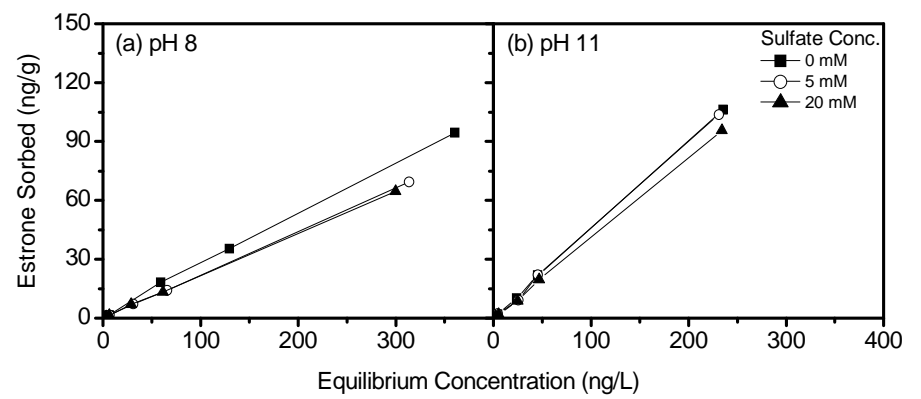




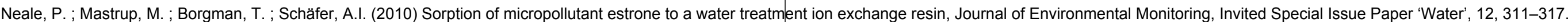
DOI: 10.1039/B913338K

Figure 8

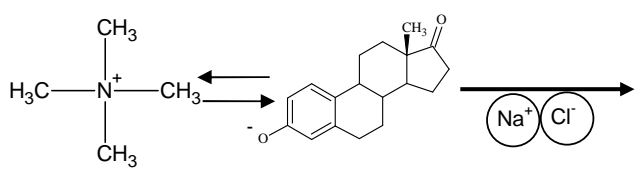

Ion Exchange
$\mathrm{NaCl}$

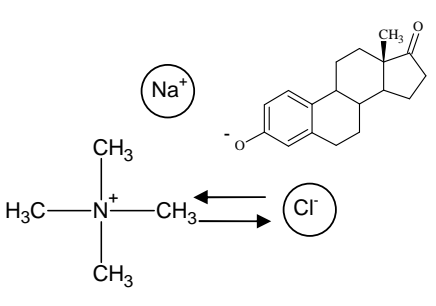

Ion Exchange Reversal
Figure 9

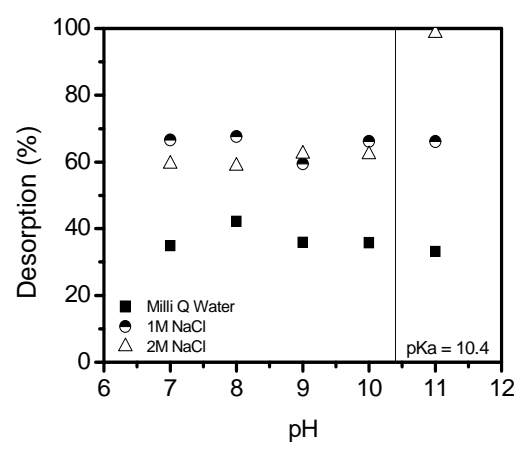

